\title{
Monetary policy, income and prices: a stability assessment
}

\author{
HAKAN BERUMENT* and HAKAN TAŞÇI \\ Department of Economics, Bilkent University, Ankara, Turkey. \\ E-mail: berument@bilkent.edu.tr
}

This paper assesses the stability of the money-income relationship for seven OECD countries. When the sample was split into two subsamples: pre- and post-1980, the empirical evidence presented in this paper shows that even if the inferences gathered across countries are not always parallel, the inferences gathered from the VAR specification across the samples for each country are mostly parallel.

\section{INTRODUCTION}

The effect of monetary policy on income is one of the most popular research areas in economics. There exist numerous studies that try to assess the effect of monetary policy on income for different countries and for different periods. Various methods are used to identify the monetary policy; Christiano et al. (1997) categorize this identification within three groups. The first group of studies identifies all the changes in the instrument of monetary policy that are not explained by the monetary authorities' feedback rule (for example, Sims and Zha, 1995; Leeper et al., 1996). The second class of classification identifies monetary policy shocks by the assumption that monetary policy does not affect economic activity in the long run (for example, Blanchard and Quah, 1989; Faust and Leeper, 1997; Pagan and Robertson, 1995). The third class of strategy observes the data and tries to find the variables that identify the monetary policy (for example, Cooley and Hansen, 1989, 1997; Romer and Romer, 1989; Christiano, 1991; King, 1991; Bernanke and Blinder, 1992; Sims, 1992; Christiano and Eichenbaum, 1995; Rudebusch, 1995).

In his highly cited paper, Sims (1992) provides empirical evidence on the effect of monetary policy in five developed countries. In his paper, monetary policy shock is identified by the innovation of short-term interest rates. By using the unconstraint vector autoregressive method, Sims (1992) analyses the money-income relationships for France, Germany, Japan, the UK and the US. He finds that the response of all real output to interest rate innovations is similar for all five countries. Even if all the results gathered on the effect of interest rates or money aggregates are parallel in all the countries, in each cases contractionary monetary shocks lead to a negative output response.

In contrast, Friedman and Kuttner (1992) argue that the money-income relationship breaks down after the 1980 s for the US. Including the data from the 1980s, the period of rapid innovation in financial markets, they note that the time series evidence indicating the relationship between money aggregate and nominal income or real income weakens. They get strong evidence on the apparent breakdown in the 1980s. Moreover, the significance of this breakdown changes according to the variables that are used to investigate the relationship. Berument and Froyen (1998) also provide evidence on the instability of the money-income relationship for the UK. Bernanke and Mihov (1995), Strongin (1995) and Christiano et al. (1999) find that the stability of the dynamic response of the economic performance to monetary policy are not qualitatively different for the US across different subsamples.

This study tests if any instability exists for the moneyincome relationship after 1980 by using the unconstraint vector auto regressions (VAR) for seven OECD countries within Sims' (1992) framework. The countries are: Canada,

\footnotetext{
* Corresponding author.
} 
France, Germany, Italy, Japan, the US and the UK. After estimating VAR specifications for seven countries and for different samples, the paper concludes that the results of the full sample as well as the two subsamples are parallel with Sims (1992).

In the second part, the methodology that is used in this paper will be discussed. Then in the third section the empirical findings are interpreted. Section IV is for the conclusion.

\section{METHODOLOGY}

In this paper, the exogenous part of the monetary policy is identified by using the orthogonalized innovation to shortterm interest rates. Following Sims (1992), an unconstrained six-variable vector auto regressions model is specified. These six variables from Canada, France, Germany, Italy, Japan, the UK and the US enter the specification in the following order: a short term interest rate (differs with respect to each country treasury bill rate and interbank rates are used), an exchange rate, world level commodity prices, a money supply measure (M1, but in some cases M0), the consumer price index and seasonally adjusted industrial production. Except for the short-term interest rate, all the variables are entered as logarithms where interest rate is used as a percentage. All the data were taken from IFS or OECD Main Economic Indicators and the codes of the data and sample sizes can be seen in Appendix B. In order to account for seasonality, additive dummy variables are included for all the estimations. Each variable in each of the equations is entered with 14 lags. The impulse response functions are shown over an expanse of 48 periods.

The ordering of the variables in the VAR specification is important. Christiano et al. (1996) elaborate on the importance of the ordering. In this specification, the interest rates are used as the first variable; therefore, this specification assumes that the short-term interest rate affects all the variables contemporaneously. It is not affected by any of the variables that the estimation includes. Neither does industrial production have an effect on any of the other variables. This set of ordering implies that the Central Bank sets its reaction function by observing the lagged values of these six variables but exchange rates are affected by all the lagged values and the current level of interest rates.

\section{EMPIRICAL EVIDENCE}

As discussed in the previous part, there are three methods for measuring the stance of monetary policy. Parallel to Sims (1992) as well as Bernanke and Blinder (1992) and
Friedman and Kuttner (1992), the third method to assess the monetary policy is used here. The main motive of the choice of the method is to observe the stability of the money-income relationship within the recursive system rather than comparing these methods. The orthogonalized residuals to both short-term interest rates and money will be used as indicators of the monetary policy.

Before starting to report the empirical findings, brief notes are provided on the expected movements of the macro variables used in the VAR specification. In a monetary contraction, interest rates rise initially and monetary aggregates fall immediately. After this initial rise in interest rates, because of the deflationary pressure of a monetary contraction, interest rates begin to move in reverse order. Secondly, if the monetary contraction is really exogenous, the price level declines and output level does not increase.

The effect of interest rate increases on exchange rates differs according to leads to the interest rates. A contractionary monetary policy for a given expected inflation rate will cause an appreciation in exchange rates. However, according to the Fischerian point of view, when the expected inflation rate increases, depreciation in exchange rates can be seen.

\section{Responses to interest rates}

Figures 1-3 report the impulse response functions when there is one standard deviation shock to orthogonalized residuals of short-term interest rates for the three samples considered. The middle line shows the point estimates, the other two lines show the $5 \%$ confidence intervals. Standard errors are computed by using the Monte Carlo simulations with 500 draws from the estimated asymptotic distribution of the VAR coefficients. Figure 1 reports the responses of the six macroeconomic variables to interest rate innovations for the seven countries by considering the full sample. Figures 2 and 3 report the responses for the first and second subsamples, respectively. ${ }^{1}$ For the full sample analysis, Row 4 suggests that there is a negative response to money and Row 6 suggests that there is a negative response after an initial increase in output in almost all of the seven countries. These results are mostly on a parallel with Sims (1992). The effect of this monetary contraction on prices seems to be consistent for all countries. The evidence also suggests that positive innovation in interest rates increases prices, hence the price puzzle is present. These are also parallel to Sims (1992).

Next, the response of the exchange rate to tight monetary policy is discussed (Row 2). The Mundell and Fleming model suggests that tight monetary policy increases the value of the domestic currency initially. However, if the uncovered interest rate parity holds, there should be a

\footnotetext{
${ }^{1}$ Sample sizes for the full and subsamples for each country are reported in Appendix A.
} 

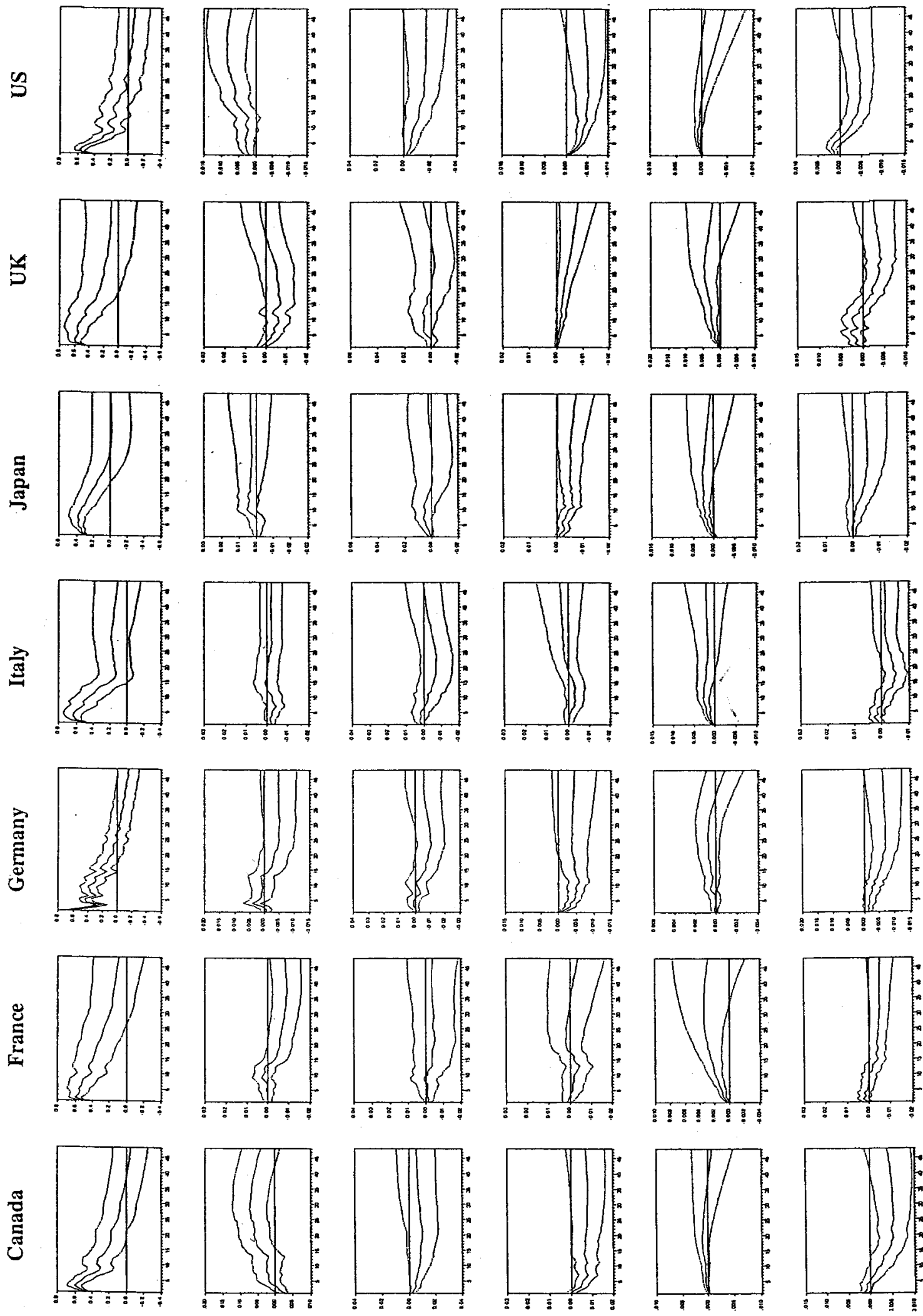

嗪

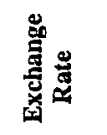

旁暴

홍

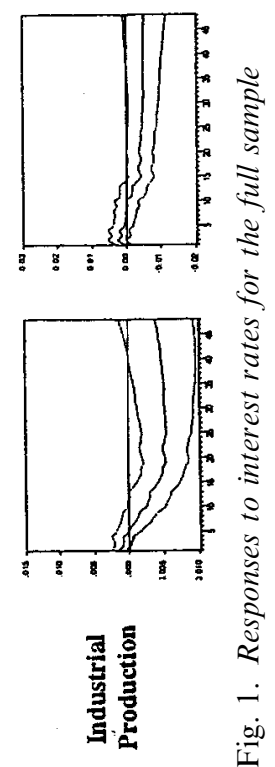



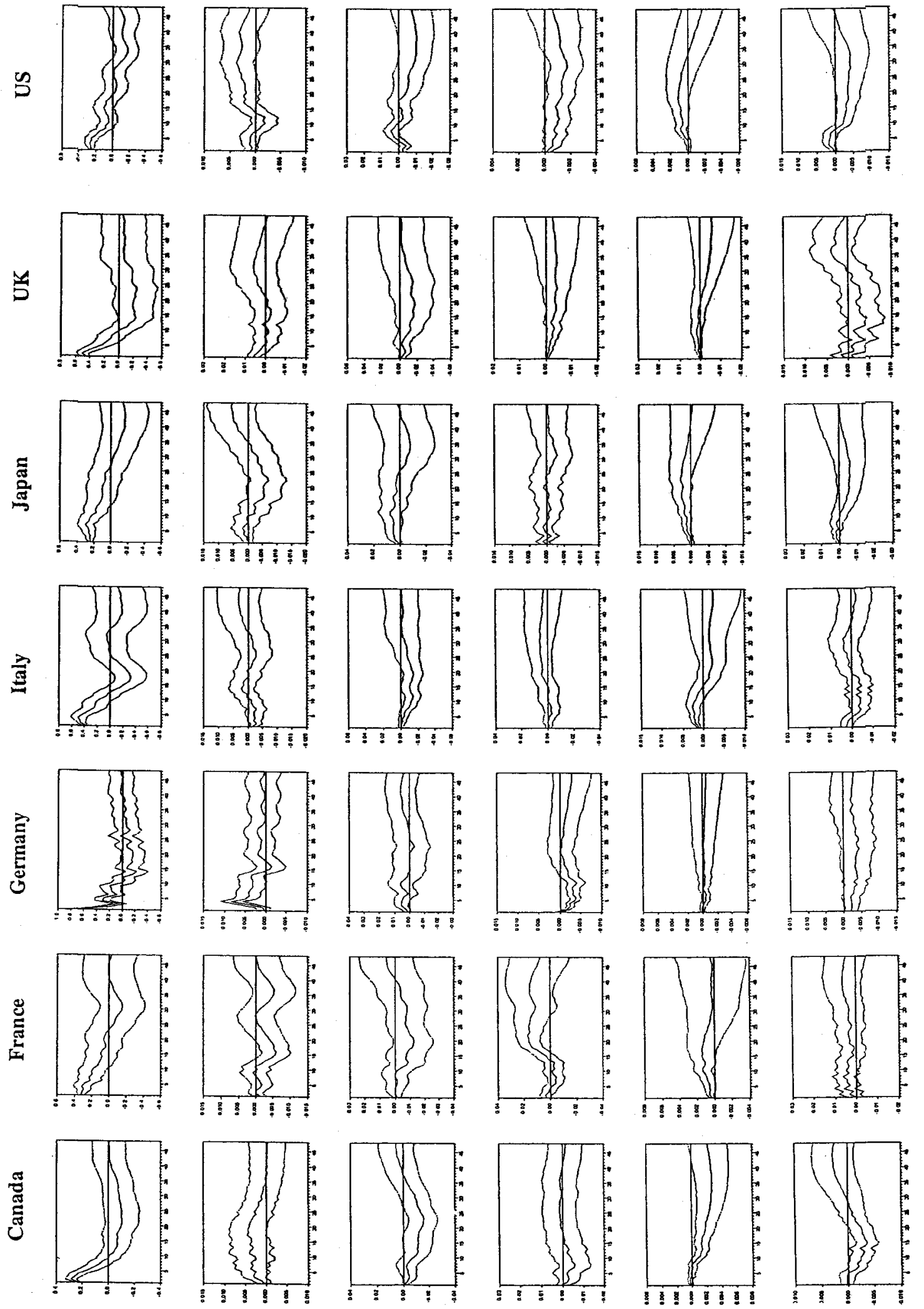

藅

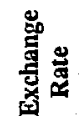

翣暴

衰
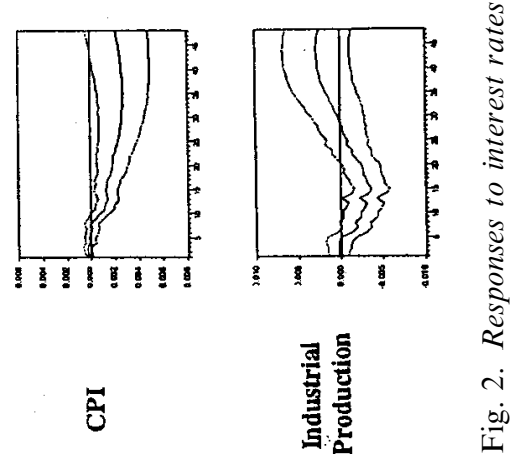

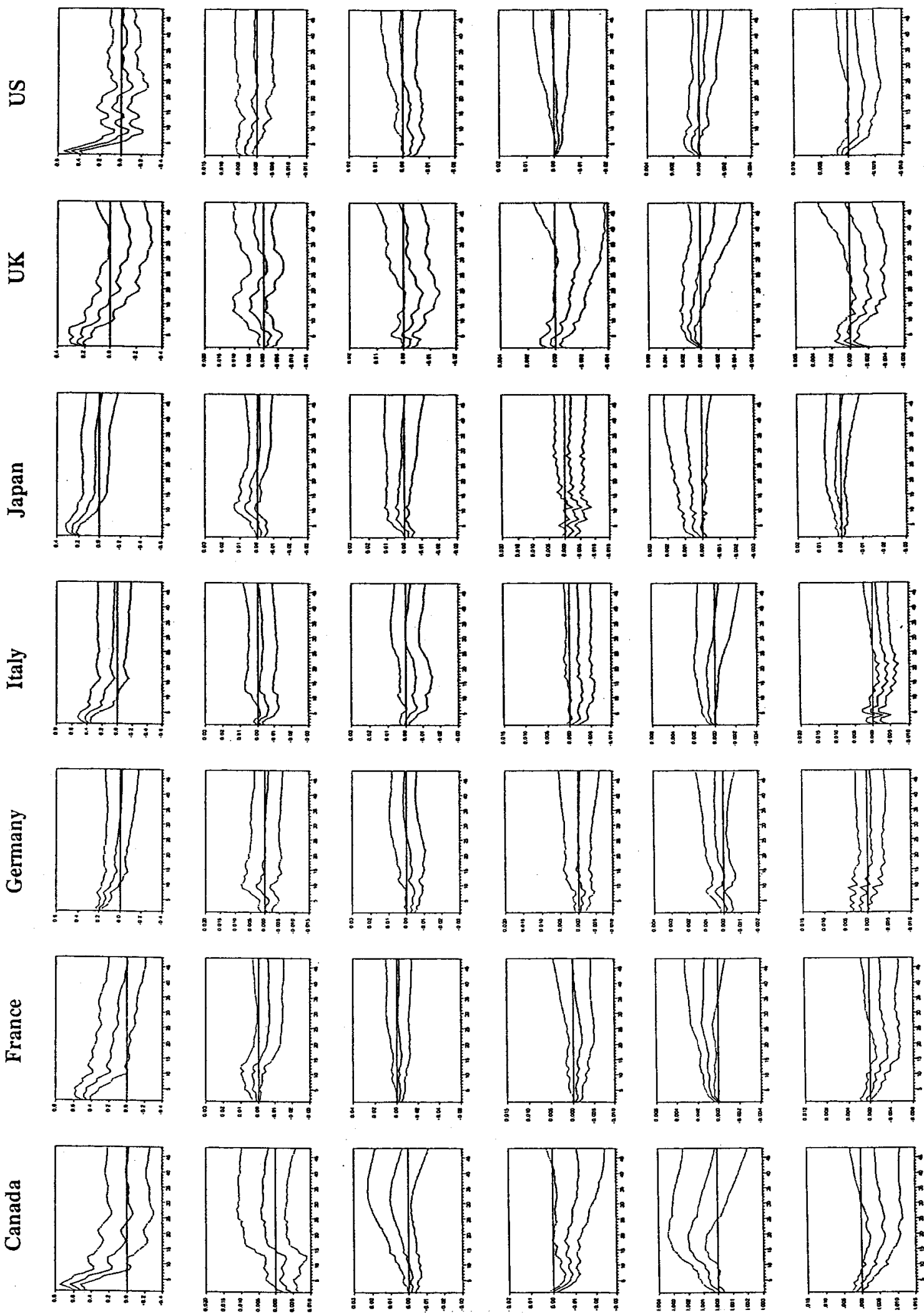

器羍

变

旁品

高

뭉

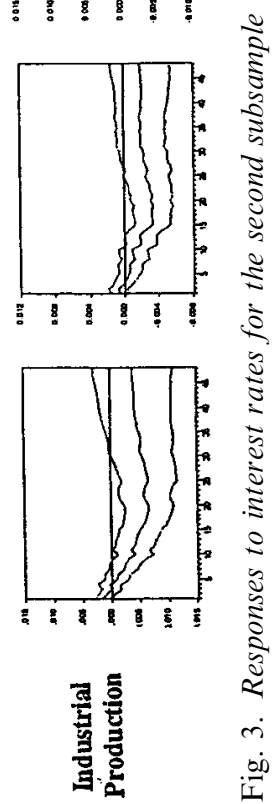



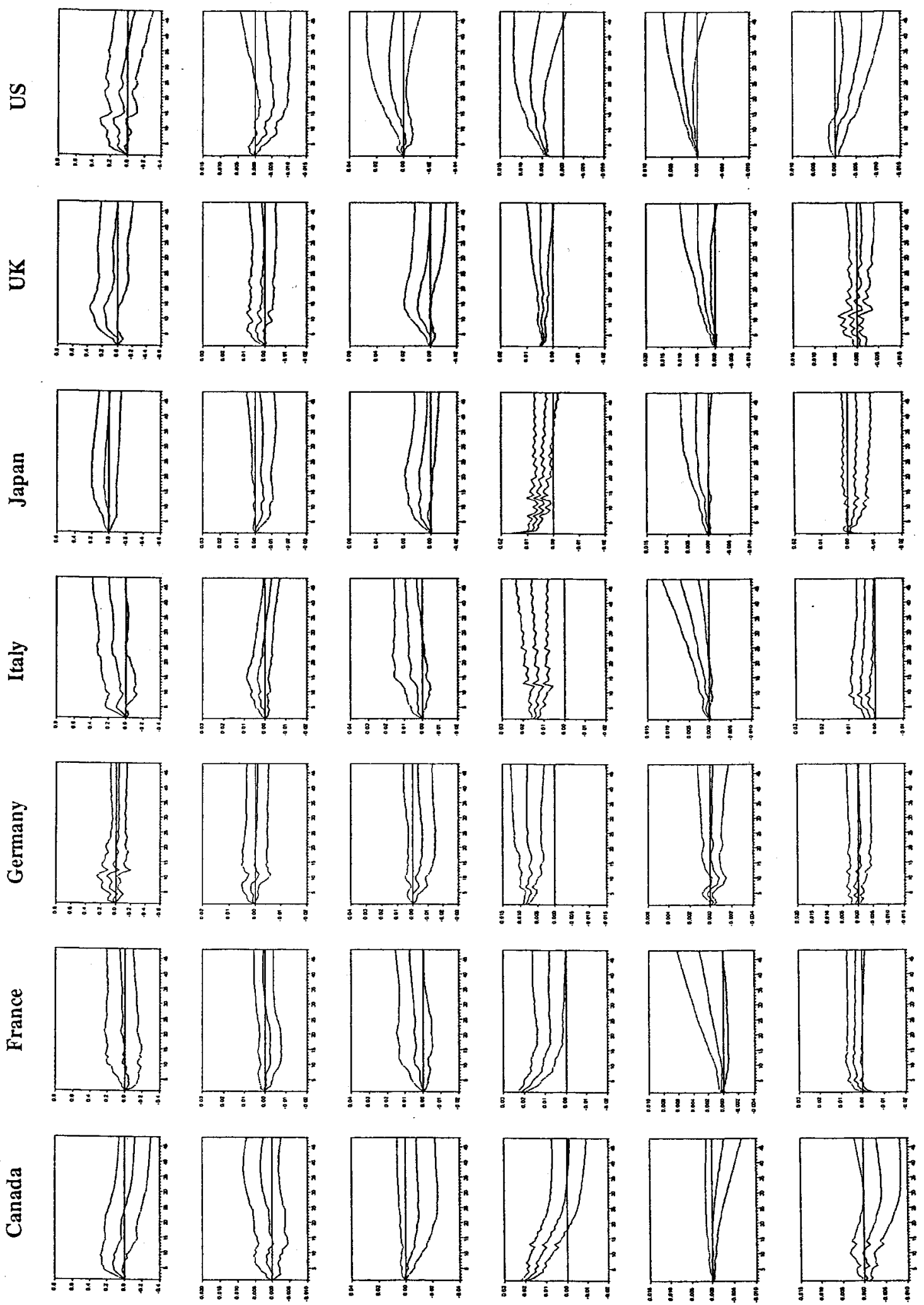

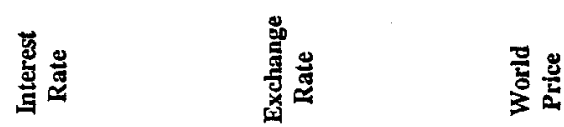

高

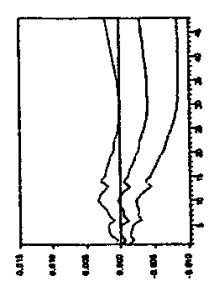

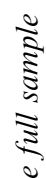



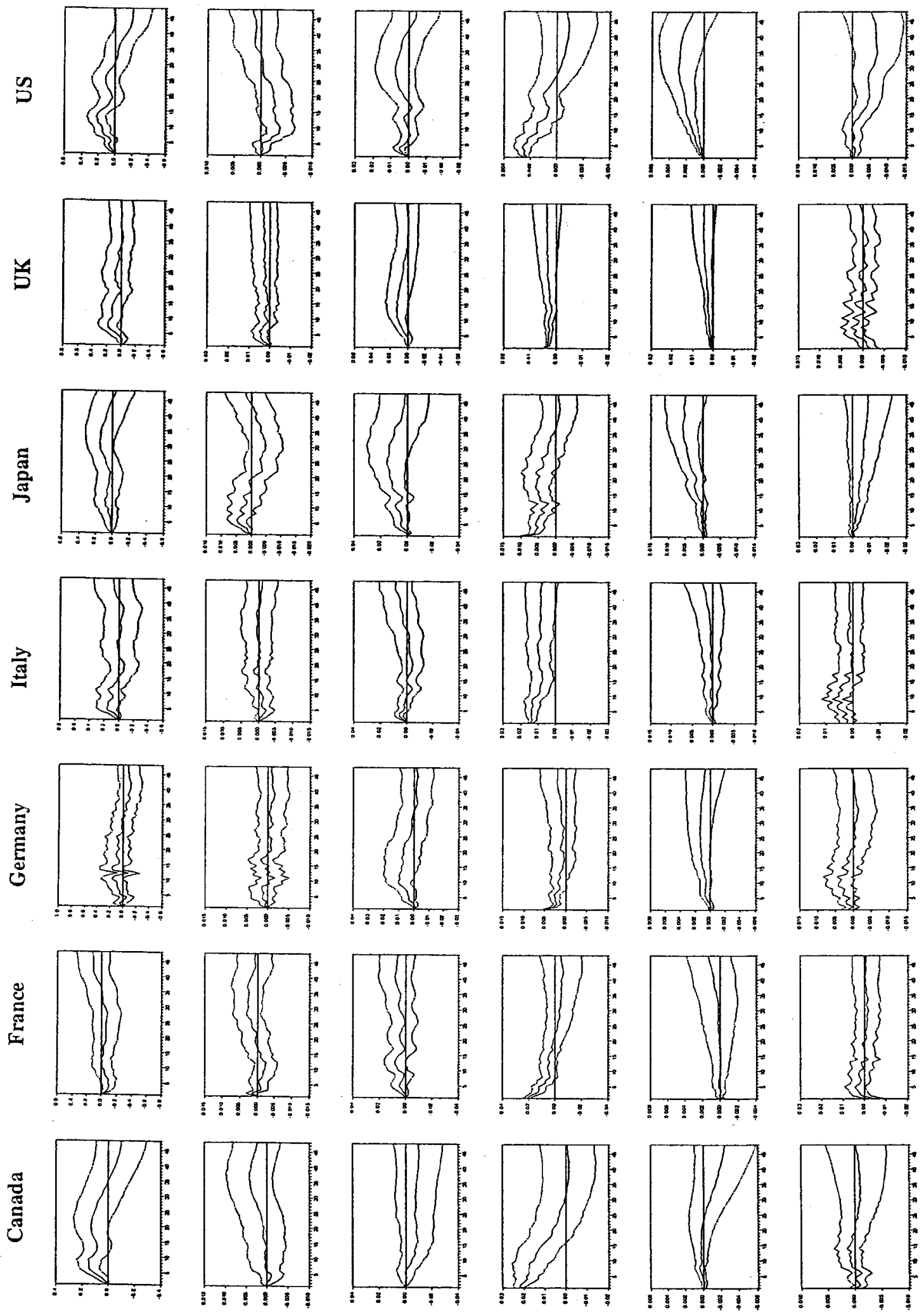

紫

离

翣薏

景

ฐ

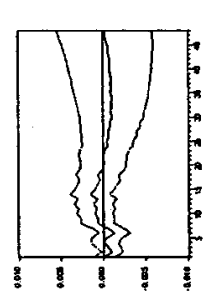

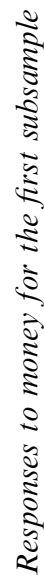

존 혼 

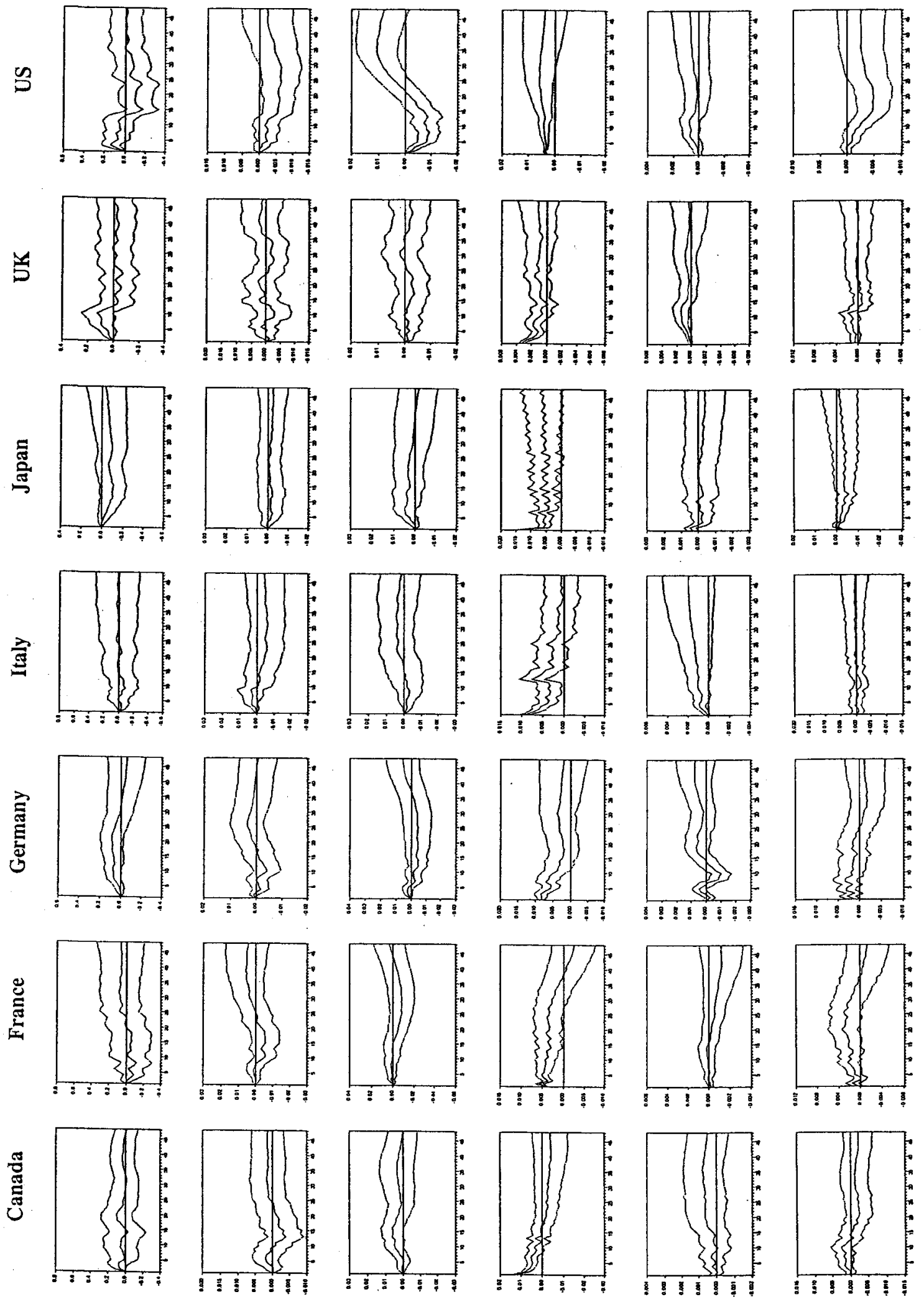

蓄

is

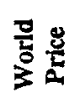

롤

ธี

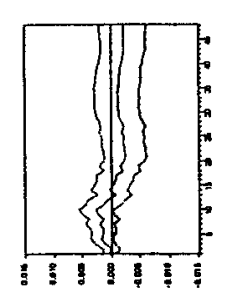

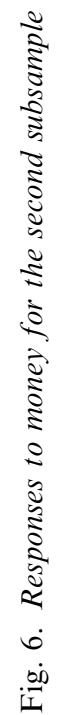


persistent decrease in the value of the domestic currency (see: Eichenbaum and Evans, 1995; Kim and Roubini, 2000). The exchange rate puzzle (with a tight monetary policy, there is an initial appreciation of the domestic currency) is not present for the UK and the US. The puzzle is present for Canada, Germany and Italy. The results on Germany, the UK and the US are parallel, but the evidence presented here for France is inconclusive. Figures 2 and 3 repeat the analyses for two subsamples for the seven countries. The evidence presented in both subsamples as well as the full sample are mostly parallel. Evidence from France, Italy, Japan and the UK are consistent among the samples. For the other three countries, the results are also mostly parallel but (i) the price puzzle as well as the exchange rate puzzle are present in the first subsample for Canada; (ii) output tends to increase then decrease for Germany in the second subsample; and (iii) commodity prices increase in the seventh month of the year for the US in the first subsample.

\section{Responses to money}

Cooley and Hansen (1989, 1997), Christiano (1991), King (1991) and Christiano and Eichenbaum (1995) argue that movements in money aggregation can be used as a measure of monetary policy. Therefore the results are reported by using the innovations in money as the indicator of the monetary policy where the order of the variables and the former orthogonality assumptions are still valid. Figures 4 6 represent the responses of all six variables to money. Figure 4 reports responses to money for seven countries by using the full sample estimates. Figure 5 performs impulses for the first sub-sample and Fig. 6 reports the impulses for the second subsample.

Figure 4 suggests that the liquidity puzzle (an increase in interest rates rather than a decrease with the positive innovation in money) is present for all the countries considered except for France. Sims (1992) also provides similar results, but the liquidity puzzle is present for the UK, not for France, in his study. When the present results are compared across the subsamples, the results are mostly parallel with the full sample but the liquidity puzzle is eliminated for Japan in the second subsample.

The impulses of exchange rates and prices for the five countries that Sims (1992) consider are parallel to those reported here. When the present results from the full sample across the subsamples are compared the results are also robust.

\section{CONCLUSION}

This paper provides empirical evidence on the subsample stability of Sims's (1992) influential work on macroeconomic time series facts, where he introduced the very pop- ular six variable VAR settings. The VAR specification that Sims (1992) used is first re-estimated by adding two additional countries that were not in his sample: Canada and Italy in addition to France, Germany, Japan, the UK and the US. Then the full sample was split into two subsamples: pre- and post-1980. The results with the full sample as well as the two subsamples are parallel to Sims (1992). Even if some puzzles like the price, the exchange rate and the liquidity puzzles remain to be addressed, it is important that the nature of the relationship is intact across the samples. Even if future research is necessary, the stability of relationships across samples provides reasons to believe that the findings of other papers that address the above puzzles with different VAR specifications are also robust across different samples.

\section{REFERENCES}

Bernanke S. B. and Blinder S. A. (1992) The federal funds rate and the channels of monetary transmission, American Economic Review, 82, 901-21.

Bernanke S. B. and Mihov, I. (1998) Measuring monetary policy, Quarterly Journal of Economics, 113(3), 869-902.

Berument H. and Froyen R. T. (1998) Potential information and target variables for UK monetary policy, Applied Economics, 30, 449-63.

Blanchard, O. and Quah, D. (1989) The dynamic effects of aggregate demand and supply disturbances, American Economic Review, 79, 655-73.

Christiano, L. J. (1991) Modeling the liquidity effect of a money shock, Federal Reserve Bank of Minneapolis, Quarterly Review, 15(1), 3-34.

Christiano, L. J. and Eichenbaum, M. (1995) Liquidity effects, monetary policy and the business cycle, Journal of Money, Credit and Banking, 27(4), 1113-36.

Christiano J. L. Eichenbaum, M. and Evans, C. L. (1996) Identification and the effects of monetary policy shocks, in Financial Factors in Economic Stabilization and Growth (ed., M. I. Blejer, Z. Eckstein, Z. Hercowitz and L. Leiderman), Cambridge University Press, pp. 36-74.

Christiano, L. J., Eichenbaum, M. and Evans, C. L. (1997) Sticky price and limited participation models: a comparison, European Economic Review, 41(6), 1201-49.

Christiano J. L., Eichenbaum, M. and Evans, C. L. (1998) Monetary policy shocks: what have we learned and to what end?, Handbook of Macroeconomics, Vol. 1A, Chapter 2.

Cooley, T. F. and Hansen, G. D. (1989) The inflation tax in a real business cycle model, American Economic Review, 79(4), 733 48.

Cooley, T. F. and Hansen, G. (1997) Unanticipated money growth and the business cycle reconsidered, Journal of Money, Credit and Banking, 29(4), 624-48.

Faust, J. and Leeper, E. M. (1997) When do long-run identifying restrictions give reliable results?, Journal of Business and Economic Statistics, 15(3), 345-53.

Friedman, B. M. and Kuttner, K. N. (1992) Money, income, prices and interest rates, American Economic Review, 82, $472-92$. 
Kim, S. and Roubini, N. (2000) Exchange rate anomalies in the industrial countries: a solution with a structural VAR approach, Journal of Monetary Economics, 45, 56186.

King, R. (1991) Money and business cycles, unpublished manuscript, University of Rochester.

Leeper, E. M., Sims, C. A. and Zha, T. (1996) What does monetary policy do?, Brookings Papers on Economic Activity, 2, 163.

Pagan, A. R. and Robertson, J. C. (1995) Resolving the liquidity effect, Federal Reserve Bank of St. Louis Review, 77(3), 3354.

Romer, C. D. and Romer, D. H. (1989) Does monetary policy
Matter? A New Test in the Spirit of Friedman and Schwartz, NBER Macroeconomic Annual 1989, MIT Press, Cambridge, 121-70.

Rudebusch, G. D. (1995) Federal reserve interest rate targeting, rational expectations and the term structure, Journal of Monetary Economics, 35(2), 245-74.

Sims, C. A. (1992) Interpreting the macroeconomic Time Series Facts, European Economic Review, 36, 975-1011.

Sims, C. A. and Zha, T. (1995) Does monetary policy generate recessions? unpublished manuscript, Yale University.

Strongin, S. (1995) The identification of monetary policy disturbances, explaining the liquidity puzzle, Journal of Monetary Economics, 35, 463-98.

\section{APPENDIX A: SAMPLE SIZES}

\begin{tabular}{|c|c|c|c|c|c|c|}
\hline \multirow{2}{*}{$\frac{\text { Country }}{\text { Canada }}$} & \multicolumn{2}{|c|}{ Full sample } & \multicolumn{2}{|c|}{ First subsample } & \multicolumn{2}{|c|}{ Second subsample } \\
\hline & 1961:03 & 2000:08 & 1961:03 & 1979:12 & 1980:01 & 2000:08 \\
\hline France & 1965:03 & 1998:12 & $1965: 03$ & 1979:12 & 1980:01 & 1998:12 \\
\hline Germany & 1961:03 & 1998:12 & 1961:03 & 1979:12 & 1980:01 & 1998:12 \\
\hline Italy & 1963:03 & 1998:12 & 1963:03 & $1979: 12$ & 1980:01 & 1998:12 \\
\hline Japan & 1964:03 & 2000:08 & 1964:03 & 1979:12 & 1980:01 & 2000:08 \\
\hline UK & 1971:03 & 2000:08 & 1971:03 & $1985: 12$ & 1986:01 & 2000:08 \\
\hline US & 1961:03 & $2000: 10$ & 1961:03 & 1979:12 & 1980:01 & $2000: 10$ \\
\hline
\end{tabular}

\section{APPENDIX B: DATA}

World Prices

World

Consumer prices

Canada

France

Germany

Italy

Japan

UK

US

Industrial production

Canada

France

Italy

Germany

Japan

UK

US

Interest rates

Canada

France
IFS 00176axdzf ...

IFS $\quad 15664 \ldots$ ZF $\ldots$

IFS $\quad 13264 \ldots$ ZF ...

IFS $\quad 13464 \ldots$ ZF $\ldots$

IFS $\quad 13664 \ldots$ ZF ...

IFS $\quad 15864 \ldots$ ZF .

IFS $\quad 11264 \ldots$ ZF .

IFS $\quad 11164 \ldots$ ZF $\ldots$

IFS $\quad 15666 \ldots$ CZF ...

IFS $\quad 13266 \ldots$ CZF .

IFS $\quad 13666 \ldots$ CZF ...

IFS $\quad 13466 \ldots$ CZF ...

IFS $\quad 15866 \ldots$ CZF ...

IFS $\quad 11266 \ldots$ CZF ...

IFS $\quad 11166 \ldots$ CZF ..

IFS $\quad 15660 \mathrm{C} \ldots \mathrm{ZF} \ldots$

IFS $13260 \mathrm{~B} \ldots \mathrm{ZF} \ldots$

Italy

Germany

Japan

UK

US

Exchange rates

Canada

France

Italy

Germany

Japan

UK

US

Money

Canada (M1)

France (M1)

Italy (M1)

Germany (M1)

Japan (M0)

UK (M0)

US (M1)
OECD main economic indicators

IFS $13460 \mathrm{~B} \ldots$. ZF . .

IFS $\quad 15860 \mathrm{~B} \ldots \mathrm{ZF} \ldots$

IFS $\quad 11260 \mathrm{~B} \ldots \mathrm{ZF} \ldots$

IFS $11160 \mathrm{~B} \ldots \mathrm{ZF} \ldots$

IFS $\quad 156 \ldots$ AA.ZF $\ldots$

IFS $132 \ldots$ AA.ZF ...

OECD main economic indicators

IFS $\quad 134 \ldots$ AA.ZF ...

IFS $158 \ldots$ AA.ZF . .

OECD main economic indicators

IFS $111 \ldots$ AA.ZF ...

OECD main economic indicators

OECD main economic indicators

OECD main economic indicators

IFS 13439MACZF ...

IFS $\quad 15834 \ldots$ ZF ...

OECD main economic indicators

IFS 11159MACZF . 